\title{
Erratum to: Effects of somatosensory stimulation on corticomotor excitability in patients with unilateral cerebellar infarcts and healthy subjects - preliminary results
}

\author{
Suzete Nascimento Farias da Guarda ${ }^{1,24^{*}}$ and Adriana Bastos Conforto ${ }^{1,3}$
}

\section{Erratum}

Following publication of this work [1] the authors noticed a mistake within the article's discussion section. The original mistake and resulting clarification are outlined below:

In the discussion section (paragraph 10) where it is written:

"The increase in rMT and decrease in MEP/M at $100 \%$ rMT in the present study...”

It should read:

"The increase in rMT and increase in MEP/M at $100 \%$ rMT in the present study..."

\section{Author details}

${ }^{1}$ Hospital das Clínicas/São Paulo University, São Paulo, Brazil. ${ }^{2}$ Hospital São

Rafael, Salvador, Brazil. Instituto Israelita de Ensino e Pesquisa Albert Einstein, São Paulo, Brazil. ${ }^{4}$ Rua Waldemar Falcão n 1547 ap 1201 Horto Florestal

40.295-010, Salvador, Bahia, Brazil.

Received: 11 April 2016 Accepted: 11 April 2016

Published online: 25 April 2016

\section{Reference}

1. Farias da Guarda SN, Conforto AB. Effects of somatosensory stimulation on corticomotor excitability in patients with unilateral cerebellar infarcts and healthy subjects - preliminary results. Cerebellum \& Ataxias. 2014;1:16. doi:10.1186/s40673-014-0016-5.

\footnotetext{
* Correspondence: suzetefarias@terra.com.br

${ }^{1}$ Hospital das Clínicas/São Paulo University, São Paulo, Brazil

${ }^{2}$ Hospital São Rafael, Salvador, Brazil

Full list of author information is available at the end of the article
}

Submit your next manuscript to BioMed Central and we will help you at every step:

- We accept pre-submission inquiries

- Our selector tool helps you to find the most relevant journal

- We provide round the clock customer support

- Convenient online submission

- Thorough peer review

- Inclusion in PubMed and all major indexing services

- Maximum visibility for your research

Submit your manuscript at

www.biomedcentral.com/submit 